\title{
MODEL PENDIDIKAN KEPEMIMPINAN BERBASIS TAZKIYAH AL NAFS
}

\author{
Achmad Rizki ${ }^{1}$, Anung Al Hamat ${ }^{2}$, Muhyani $^{3}$ \\ ${ }^{1,2,3}$ Pascasarjana Ibn Khaldun Bogor \\ Rizkialisumar169@gmail.com, \\ Anung.alhamat@gmail.com, \\ yaniwongtegal@gmail.com
}

\begin{abstract}
ABSTRACK
The leadership carried out by a handful of people in living life both in an organization and himself is very far from the values that bring benefit to the people. Leaders born from a group that is not based on the purity of the soul. This study aims to create a model used by an educational institution in order to give birth to a sacred soul whose soul is formulated in a tazkiyah al nafs based leadership education model given by the La Tansa boarding school, Parakansantri, Lebakgedong, Lebak Banten. The subject of this research is the model of leadership education based on tazkiyah al nafs, which consists of planning, implementation, results and evaluation of tazkiyah al nafs based leadership education in the La Tansa boarding school. The approach in this research is action research with qualitative analysis by providing a pilot education regarding the inculcation of leadership values that is applied directly through activities, programs, and implementation of worship rituals, planting praiseworthy traits and away from reprehensible traits carried out with full awareness on the basis of the five souls and the motto of the cottage.
\end{abstract}

\section{ABSTRAK}

Kepemimpinan yang dilaksanakan oleh segelintir orang dalam menjalani kehidupan baik dalam suatu organisasi maupun dirinya sangat jauh dari nilai-nilai yang membawa kemaslahatan umat. Pemimpin yang lahir dari suatu golongan yang tidak berlandaskan atas kesucian jiwa. Penelitian ini bertujuan untuk menciptakan suatu model yang digunakan oleh suatu lembaga pendidikan dalam rangka melahirkan pemimpin yang suci jiwanya yang dirumuskan dalam model pendidikan kepemimpinan berbasis tazkiyah al nafs yang diberikan pondok pesantren La Tansa, Parakansantri, Lebakgedong, Lebak Banten. Pokok bahasan dalam penelitian ini yaitu, model pendidikan kepemimpinan berbasis tazkiyah al nafs, yang terdiri dari perencanaan, pelaksanaan, hasil dan evaluasi pendidikan kepemimpinan berbasis tazkiyah al nafs di pondok pesantren La Tansa. Pendekatan dalam penelitian ini adalah action research dengan analisis kualitatif dalam memberikan pendidikan percontohan mengenai penanaman nilai-nilai kepemimpinan yang diaplikasikan secara langsung melalui kegiatan-kegiatan, program, dan pelaksanaan baik ritual peribadatan, penanaman sifat-sifat terpuji dan menjauhi dari sifat-sifat tercela yang dilaksanakan dengan penuh kesadaran atas dasar panca jiwa dan moto pondok.

Keyword: education, leadership, tazkiyah al nafs

\section{PENDAHULUAN}

Krisis kepemimpinan dalam suatu lingkungan sosial yang berujung kepada kurangnya mutu dan nilai keputusan yang berkesan kurang baik kepada kehidupan dalam tatanan sosial ini dapat berdampak atas kesenjangan sosial yang terjadi di masyarakat yang mana di dalamnya terdapat perserikatan untuk memenuhi kepentingan - kepentingan tertentu. 
Peristiwa ini dapat dilihat dengan adanya seorang memimpin yang tidak berlandaskan atas pendidikan, pelatihan dan pengalaman yang cukup sehingga segala keputusannya diambil berdasarkan atas egosentris.

Dengan kurangnya pengontrolan pada diri seseorang sehingga potensi sumber daya manusia dalam dirinya kurang berkembang dengan mengabaikan potensi self leadership dari dalam. Pada zaman global ini pemimpin yang dibutuhkan adalah pemimpin yang superleader yang didasari atas penguatan self leadership (Kahyo, 2005)

Islam memandang kepemimpian sangatlah dipentingkan sebagaimana yang dicontohkan Rasulullah 細 memimpin umat ini setelah itu kepemimpinan yang dilanjutkan oleh para sahabat yang disebut sebagai khilafah. Khilafah adalah pemerintahan yang dipilih secara demokratis yang diangkat melalui pemilihan langung oleh rakyat serta terikat dengan hukum-hukum konstitusi negara yaitu islam dan mempertanggung jawabkannya kepada rakyat yang bertujuan untuk menegakan hukum-hukum Allah dan terciptannya keadilan dan prinsip luhur kemanusiaan. (Dhia'uddin, 2002)

Khalifah diartikan sebagai perwakilan dalam rangka mengatur dan mengurus atas setiap perkara yang ada di dunia sebagai sebuah kepemimpinan. Kepemimpinan adalah pesona prilaku seseorang dalam upaya mempengaruhi orang lain baik individu maupun kelompok untuk tercapainya tujuan. (Falah, 2012)

Kepemimpinan dari level terkecil yaitu atas pribadinya maupun pada level tertinggi misalnya kepala negara. Pemimpin dalam suatu negara sangat berpengaruh atas kesejahteraan rakyatnya karena pemimpin yang lahir dari kebersihan baik dari segi jasmani maupun rohani akan berpegang teguh kepada kebenaran yang benar bukan hanya membenarkan kenyataan yang ada untuk mencapai suatu tujuan yang telah ditetapkan.

Kekhalifahan yang pertama dimulai oleh sahabat Rasulullah yang bernama Abu Bakar pada tahun 11 Hijriyah yang dibaiat melalui kaum Muhajirin dan Anshar bertempat di Tsaqifah kebun Bani Sa'idah. (Mubarakfuri, 2001)

Kepemimpinan sepeninggal Abu Bakar As Shidiq dilanjutkan dengan Umar Ibn Khattab, Utsman Ibnu Affan dan Ali Ibn Abi Thalib yang dikenal dengan Khalifatu Ar Rassyidin. Kehadiran kepemimpinan pada Khulafah Ar Rasyidin ini sebagai bentuk implementasi atas kemurnian tazkiyah al nafs yang dibimbing langsung oleh Rasulullah 繼 melalui kemurnian tauhid, pemahaman atas syariah yang dalam, pengamalan ibadah-ibadah yang menjadi salah satu cara dalam upaya melindungi atas bisikan syaitan. Sehingga 
kekhalifah yang diakui dan dipilih secara majlis syuro ini berakhir pada masa kekhalifahan Ali Ibn Thalib. (Fadhlali, 2004)

Cerminan dari karakteristik kepemimpinan yang ditampilkan dalam kancah Islam ini terjadi disebabkan karena penanaman akan nilai-nilai pendidikan yang teguh dari penanaman akidah yang kuat, pembiasaan akan akhlaq dalam diri, hingga penanaman akan ilmu pengetahuan yang luas serta penerapan dan pengamalam dalam sehari-hari dalam rangka meningkatnya nilai-nilai ketaqwaan kepada Allah dengan selalu menjalankan perintah-Nya dan berusaha dengan sekuat hati untuk menjauhi segala apa yang dilarang-Nya baik yang termaktub dalam firman-Nya maupun dalan sunnah nabawiyah. (Hawa, 1998)

Manusia memiliki kewajiban untuk belajar dan mendapatkan pendidikan agar mendapatkan ketenangan didalam diri manusia tersebut untuk menjalankan kepemimpinan sebagai khalifah. (Arifin, 2014)

Pendidikan merupakan suatu proses persiapan fase awal pertumbuhan manusia yang dilakukan oleh setiap lembaga formal maupun non formal dalam menciptakan generasi yang unggul untuk mempersiapkan masa depan. (Falah, 2012)

Dalam pendidikan Islam memiliki tujuan khusus untuk membentuk kepribadian muslim yang menjadi insan kamil yang meliputi aspek prilaku, sikap, penampilan kebiasaan dan pandangan. (Drajat, 2009)

Pendidikan yang diberikan kepada setiap individu muslim dalam rangka menyiapkan generasi yang unggul dan bermutu seyogyanya pendidikan yang tidak hanya melihat dalam pandangan jasmani melainkan pandangan rohani yang sesuai dengan kaidah keagamaan sehingga mendatangkan generasi penerus yang tidak hanya memiliki keilmuan secara satu dimensi atau memandang bidimensional yakni memisahkan antara ilmu umum dan agama ini justru akan jauh dalam tujuan pendidikan yang seutuhnya dalam rangka membentuk generasi penerus yang berimtek dan berimtaq yang akan berimbas kepada ketenangan dalam diri. (Ahmad Tafsir, 1994)

Dalam upaya membentuk generasi yang unggul yang memiliki kecerdasaan, integritas yang tinggi untuk melahirkan para pemimpin tangguh yang bersih dari sifat yang dapat menjatuhkan martabat, moral pemimpin tersebut sebaiknya sebagai peletak dasar dengan melakukan proses penyucian jiwa sebagai langkah proses awal untuk membersihkan sifatsifat manusia yang akan dapat mengotori hati dan pola pikir pemimpin sehingga hasil berpikirnya menjadi tidak bermutu yang akan membawa kepada ketenangan jiwa dapat dirasakan jikalau seseorang ingin menggapainya dengan cara mensucikan jiwa dan hatinya, 
terdapat banyak cara dalam mensucikan jiwanya walaupun pada hakikatnya bahwa manusia dilahirkan di alam dunia ini sudah secara fitrah. (Muhammad, 2007)

Penyucian diri dikenal dengan istilah tazkiyah an nafs sebagai bentuk bimbingan. yang berdasarkan kepada Al Ayyat Al-Qur'aniyah dan Al hadits An Nabawiyah yang merupakan pedoman, petunjuk serta pembeda antara hak dan batil yang jika dipelajari dan difahami bahkan diperdengarkan mampu menggetarkan jiwa bagi orang-orang yang beriman sehingga orang yang membaca ayat-ayat Al-Qur'an akan mendapatkan ketenangan bagi jiwanya.

Untuk melahirkan para pemimpin yang bermutu dan berkualitas dalam kebutuhan kehidupan dan mampu mengemban suatu tampuk kepemimpinan maka para kader-kader pemimpin sebaiknya memperoleh suatu pola pendidikan yang akan menempah dan melatih kemampuan intelektual, jasmani, rohani, mentalitas, kematangan jiwa. Hal ini dilaksanakan dalam rangka suatu proses pelatihan dan pendidikan yang diberikan agar seorang pemimpin memiliki kematangan dan kemampuan dalam melaksanakan kepemimpinan. (Shadily, 1989)

Dalam rangka suatu upaya dalam untuk melahirkan pemimpin yang ideal dan bermutu maka dibutuhkan suatu cara dengan menerapkan model pendidikan kepemimpinan berbasis tazkiyah al nafs di pondok pesantren yang dilaksanakan dalam program dan kegiatan di pondok pesantren. Model pendidikan kepemimpinan berbasis tazkiyah al nafs adalah suatu percontohan dasar dalam memberikan landasan dasar untuk dijadikan suatu pedoman dalam pendidikan guna melahirkan para pemimpin yang berdasarkan atas tazkiyah al nafs yang diaplikasikan dalam kegiatan dan rutinitas sehari-hari.

\section{TINJAUAN PUSTAKA}

\section{Model Pendidikan Kepemimpinan}

Untuk melahirkan para pemimpin yang bermutu dan berkualitas dalam kebutuhan kehidupan dan mampu mengemban suatu tampuk kepemimpinan maka para kader-kader pemimpin sebaiknya memperoleh suatu pola pendidikan yang akan menempah dan melatih kemampuan intelektual, jasmani, rohani, mentalitas, kematangan jiwa. Hal ini dilaksanakan dalam rangka suatu proses pelatihan dan pendidikan yang diberikan agar seorang pemimpin memiliki kematangan dan kemampuan dalam melaksanakan kepemimpinan. (Shadily, 1989) 
Dalam Kamus Besar Bahasa Indonesia model adalah pola yang terdiri dari contoh, acuan, ragam, dasar dari sesuatu yang akan dibuat atau yang dihasilkan. Model adalah representasi dari suatu objek, benda, atau ide-ide dalam bentuk yang disederhanakan yang didapatkan dari kondisi atau kejadian alam yang berisi atas informasi untuk dipelajari baik berupa fenomena yang didapat, model dapat juga berupa tiruan dari suatu benda, sistem atau kejadian yang penting untuk dipelajari dan ditelaah. (Achmad, 2008)

Pendidikan adalah upaya untuk menyiapkan generasi penerus yang kelak akan menjalankan peran sebagai khalifah (wakil) Allah di muka bumi, untuk melahirkan seorang khalifah yang beriman dan bertaqwa maka pendidikan sebaiknya memiliki dua nilai yaitu nilai sains yang berisikan keilmuan dan nilai keislaman untuk meningkatkan keimanan dan ketaqwaan. (Muhyani., Herawati. S., 2019)

Kata tarbiyah mengandung makna perbaikan (al islah), tumbuh dan bertambah (an nama' wa az ziyadah), tumbuh dan berkembang (nasya'a wa tara), mengatur dan mengendalikan urusan(sasa wa tawalla amrahu) dan pengajaran (at ta'lim), bertambah (az ziyadah), tumbuh (an nuтuwu), berkembang (an nasy'ah), perbaikan (al islah), memberikan asupan (at taghdziyah), dan memelihara (ar ri'ayah). (Hamat, 2015)

Pendidikan merupakan suatu tindakan yang digunakan oleh sekelompok manusia baik masyarakat, kebudayaan atau kelangsungan peradaban untuk menjaga kelestarian untuk kelanjutan kehidupan masa depan. Dengan demikian pendidikan dibutuhkan kepada setiap generasi penerus untuk menjalani kehidupannya di masa depan. (Langgululung, 1995)

Pendidikan merupakan suatu kebutuhan bagi individu guna menjalani kehidupan dari masa ke masa. Yang merupakan proses timbal balik dari tiap pribadi manusia dalam penyesuaian dengan alam maupun teman. Hal ini disebabkan karena pendidikan merupakan perkembangan yang terorganisir dan kelengkapan dari semua potensi manusia, moral, intelektual dan jasmani untuk pribadi maupun masyarakat. (Zuhairi, 2009)

Pendidikan merupakan suatu proses persiapan dan pengusahaan pada fase awal pertumbuhan manusia yang dilakukan oleh setiap lembaga formal maupun non formal dalam menciptakan generasi yang unggul untuk mempersiapkan masa depan. (Falah, 2012)

Pendidikan yang bertujuan untuk meningkatkan keimanan dan ketakwaan dan akhlak mulia bagi peserta didik sebagai wadah untuk mencerdaskan generasi penerus bangsa. Dalam pendidikan Islam memiliki tujuan khusus untuk membentuk kepribadaian muslim yang menjadi insan kamil yang meliputi aspek prilaku, sikap, penampilan kebiasaan dan pandangan. (Drajat, 2009) 
Proses pendidikan dalam rangka membentuk pemimpin akan berlangsung efektif bilamana kepribadian pemimpin memiliki aspek bahwa ia menyadari untuk cinta terhadap kebenaran dan beriman kepada Tuhan yang Maha Esa, dapat dipercaya dan mampu mempercayai orang lain, mampu bekerja sama dengan orang lain, ahli dibidangnya dan senang bergaul, ramah tamah, suka menolong dan memberikan petunjuk pengabdian, memiliki kesetiaan yang tinggi, kreatif dan penuh inisiatif, bertanggung jawab dalam mengambil keputusan, konsekuensi, berdisiplin dan bijaksana, dan aktif memelihara kesehatan jasmani dan rohani dalam melaksanakan suatu kepemimpinan. (Rivai, 2009)

Kepemimpinan berasal dari bahasa Inggris dari asal kata leadership, yang bermakna pemimpin, kepemimpinan. (Shadily, 1989) Selain itu juga kepemimpinan juga merupakan petunjuk, pemandu, penuntun, komandan (Alle, 1969)

Kepemimpinan adalah seseorang yang memimpin dengan cara memprakarsai tingkah laku sosial yang terjadi di masyarakat dengan mengatur, mengarahkan, mengorganisir, atau mengontrol usaha orang lain melalui proses, kekuasaan atau oposisi. (Pratt, 1960)

Kepemimpinan merupakan suatu proses yang dialami manusia dalam kehidupan sosial. Artinya dalam kehidupannya manusia membutuhkan pemimpin dan kepemimpinan guna mencapai hasil yang spesifik dan bermanfaat melalui orang lain dan untuk diri sendiri maupun untuk orang lain dengan cara konsisten, efesien dan efektif . (Selekta, 2008)

Menurut Robbins kepemimpinan adalah kemampuan seseorang untuk mempengaruhi suatu kelompok untuk pencapaian tujuan. Adapun bentuk pengaruh tersebut bisa secara formal seperti tingkat manajerial pada suatu organisasi. Karena posisi manajemen terdiri atas tingkatan yang biasanya menggambarkan otoritas, seorang bisa mengasumsikan suatu peran kepemimpinan sebagai akibat dari posisi yang ia pegang pada organisasi tersebut. (Robbins, 2002)

Menurut Siagian kepemimpinan adalah kemampuan seseorang untuk mempengaruhi orang lain, dalam konteks ini para bawahannya sedemikian rupa sehingga orang lain itu mau melakukan kehendak pimpinan meskipun secara pribadi hal itu mungkin tidak disenanginya. (Sutrisno, 2011)

Menurut Fiedler kepemimpinan adalah pola hubungan antar individu yang menggunakan wewenang dan pengaruh terhadap orang lain atau sekelompok orang agar membentuk kerja sama untuk menyelesaikan suatu tugas. (Putra, 2013) 
Menurut Covey sebagaimana dikutip Sadanya suatu proses dalam kepemimpinan untuk memberikan pengaruh secara sosial kepada orang lain, sehingga orang lain tersebut menjalankan suatu proses sebagaimana diinginkan oleh pemimpin. (Muhaimin, 2012)

kepemimpinan merupakan proses mempengaruhi dan menentukan tujuan organisasi memotivasi perilaku pengikut untuk mencapai tujuan, memberikan pengaruh dalam pola perbaikan pengikut dan budaya.(Rivai, 2009)

Pemimpin adalah kepribadian seseorang yang memiliki kemampuan dan kelebihan khususnya pada spesialisasi bidang tertentu sehingga ia mampu memberikan pengaruh kepada orang lain untuk bersama-sama melakukan aktivitas tertentu, demi pencapaian satu atau beberapa tujuan yang telah ditentukan. (W.I., 2015)

Untuk melahirkan pemimpin yang bermutu diperlukan persyaratan yang khusus diantaranya adalah: (Burhanuddin, 2005) Personality yaitu kemampuan yang terdapat dalam kepribadian pemimpin. Purpose adalah suatu kemampuan dalam menyampikan informasi kepada orang lain. Knowledge yaitu kemampuan kecerdasan seorang pemimpin. Professional skills yaitu kemampuan dalam mengelola kepemimpinan.

Tipe kepemimpinan adalah suatu kepribadian yang diaplikasikan seorang pemimpin yang berdasarkan dari pola dasar hubungan kerja diantara anggotanya diantaranya adalah: (Kartono, 2010) Tipe deserter yaitu sifatnya memiliki moral yang rendah, tidak memiliki keterlibatan dalam organisasi, pengabdian, loyalitas dan ketaatan yang hilang, sukar dijadikan panutan. Tipe birokrat yaitu sifatnya kaku, patuh pda peraturan dan norma, manusia yang tepat, cermat, berdisiplin dan keras. Tipe misionaris yaitu sifatnya terbuka, penolong, lembut hati, ramah tamah. Tipe developer memiliki sifat kreatif, dinamis, inovatif, memberikan/ melimpahkan wewenang dengan baik, menaruh kepercayaan pada bawahan. Tipe otokrat memiliki sifat keras, dikatatoris, mau menang sendiri, keras kepala, sombong. Benevolent autocrat memiliki sifat lancar, tertib, ahli dalam mengorganisir, besar rasa keterlibatan diri. Tipe compromesier memiliki sifat kebimbangan, tidak memiliki pendirian, tidak dapat mengambil keputusan, berpandangan pendek dan sempit. Tipe eksekutif memiliki Sifat bermutu tinggi, dapat memberikan motivasi yang baik, berpandangan jauh, tekun.

Fungsi kepemimpinan secara operasional memiliki lima fungsi pokok diantaranya adalah: (Rivai, 2009), Fungsi intruksi yaitu fungsi yang bersifat komunikasi satu arah yang memberikan pengaruh dalam perintah dan komunikatif dalam memutuskan perkara. Fungsi konsultasi yaitu fungsi yang bersifat komunikasi dua arah dengan memberikan kesempatan 
kepada bawahan untuk memberikan saran, masukan dalam mengambil keputusan. Fungsi partisipasi yaitu fungsi yang bersifat bahwa pemimpin berusaha mengaktifkan orang yang dipimpin baik dalam ikut serta mengambil keputusan maupun dalam pelaksanaannya. Fungsi delegasi yaitu fungsi yang bersifat memberikan pelimpahan wewenang untuk membuat/menetapkan putusan baik melalui persetujuan atau tidak dari pimpinan. Fungsi pengendalian yaitu fungsi yang bersifat bahwa pemimpin yang sukses mampu mengatur aktivitas anggotanya secara terarah dan mendalam sehingga tercapainya tujuan.

Teori lahirnya seorang pemimipin dalam suatu organisasi atau masyarakat disebutkan (Burhanuddin, 2005) Teori genetis yaitu seseorang yang memiliki pandangan bahwa orang yang memiliki bakat pemimpin sejak lahir yang akan diwariskan atau dinasabkan seperti setiap pangeran, putra mahkota, putri dll.

Teori sosial yaitu pemimpin yang dilahirkan bukan karena nasab namun tercipta atas pelatihan dan pendidikan yang diberikan kepada seseorang sehingg memiliki kemampuan memimpin melalui proses sosial.

Teori ekologis yaitu seorang pemimpin yang lahir secara nasab atau keturunan sudah memiliki bakat-bakat kepemimpinan namun tetap mengembangkan potensi-potensi kepemimpinan yang dimiliki dengan memperkuat melalui pendidikan atau pelatihan kemampuan kepemimpinannya baik secara formal maupun non formal di organisasi regular maupun non regular.

Untuk melahirkan generasi pemimpin dalam Islam sangatlah mendasar dengan memahami dan memiliki dasar yang kuat diantara dasar konsep kepemimpinan dalam Islam (Rivai, 2009) adalah melalui pertama, Pendekatan Normatif yaitu pendekatan ini berdasarkan tuntunan dan anjuran yang terdapat dalam Al-Qur'an diantaranya adalah seorang pemimpin memiliki prinsip tauhid, bertanggung jawab, amanah, keadilan, kesederhanaan.

Kedua, Pendekatan Historis yaitu pendekatan yang berlatarkan atas kepemimpinan ynag terdapat didalam Al-Qur'an yang luas dan lugas dalam menceritakan bagaimana kepemimpinan kaum terdahulu seperti kepemimpinan para Rasul $\square$ selain itu juga sirrah nabawiyah, sirah shahabah yang mengambarkan para pemimpin Islam sepeninggalnya rasul $\square \square$ sebagai pelajaran yang sangat bernilai dan bermoral yang mengandung nilai-nilai kepemimpinan.

Ketiga, Pendekatan teoritik yaitu pendekatan yang mengandung teori-teori baru yang sejalan dengan segala tuntunan ideologi Islam yang seuai dengan nash-nash Islam sehingga 
melahirkan para pembaharu-pembaharu Islam yang membangun dasar konseptual yang sejalan dengan zamannya.

Model kepemimpinan Rasulullah 緰 diawali dengan penanaman akidah sebagai asas yang fundamental dan benteng pertahanan nilai-nilai keislaman seseorang muslim dan melindungi dalam menghadapi godaan yang datang. (Kahyo, 2005)

Konsep kepemimpinan Rasulullah 繿 dalam rangka menciptakan pemimpin yang handal dengan melakukan proses kaderisasi yaitu tugas untuk membentuk manusia yang siap dan bertanggung jawab atas apa yang diamanahkan oleh Allah kepadanya. Metode kaderisasi dalam melahirkan seorang pemimpin yang bertanggung jawab dan amanah (Zarkasyi, 2011)

pertama, Pengarahan adalah memberikan pemahaman mengenai kegiatan yang akan dilaksanakan, teknik dan subtansi dalam pelaksanaan kegiatan.

Kedua, Pelatihan adalah program pengembangan untuk menambah wawasan keilmuan, pemikiran dan pengalaman.

Ketiga, Penugasan adalah proses penguatan dan pengembangan diri yang didalamnya terdapat tugas dan penyelesaian tugasnya.

Keempat Pembiasaan adalah pola dalam rangka pengembangan mental dan karakter siswa dalam melakukan program yang telah ditetapkan.

Kelima, Pengawalan adalah bimbingan dan pendampingan dalam melakasanakan tugas dan kegiatan yang dilaksanakan agar mendapatkan kontrol, evaluasi dan langsung diketahui.

Keenam, Uswah hasanah adalah upaya memberikan dan menjadikan contoh yang baik kepada orang lain.

Kualifikasi bagi seorang pemimpin yaitu seseorang yang memiliki kejujuran (amanah) dan kewibawaan (al quwwah). Indikasi kejujuran seseorang dapat dilihat dari ketaqwaannya kepada Allah dengan ketidaksediaan dalam menjual ayat-ayat Allah demi kekayaan dan kepentingan politik praktis serta tidak ada rasa takut dalam dirinya selama dalam kebenaran.(Taimiyyah, 1969)

Prinsip kaderisasi Rasulullah 緙能 memiliki nilai-nilai kepribadian yang tinggi (Kahyo, 2005) yang mana mencerminkan keteladanan terhadap sifat-sifat kepemimpinan Rasulullah yang tegas dan keras dalam menegakkan disiplin amar ma'ruf nahi munkar. Kepemimpinan yang diwarnai dengan ketaatan pengikut dengan rasa kasih sayang dan tidak 
mengharapkan sesuatu kecuali karunia Allah dibarengi dengan pembinaan dan pengembangan kader sebagai generasi pelanjut. Tujuan yang hendak dicapai selalu bersih dan suci dari pengaruh dan kepentingan-kepentingan selain Allah 辂. Perumusan taktik dan strategi perjuangan senantiasa dimusyawarahkan dengan penuh bijaksana. Kelembutan dalam berkomunikasi dan keharmonisan dalam bergaul menjadi ciri khas pembinaan, sehingga siap dan teguh dalam akidah, taat beribadah yang berpaduan dengan Al Akhlak Al Karimah.

Peran kepemimpinan yang dicontohkan Rasulullah 能 dalam mempimpin kaum muslimin pada setiap masyarakat dengan menjadikan dirinya sebagai Servant yaitu seorang pemimpin merupakan seorang pelayan bagi pengikutnya. Dalam rangka menciptakan pelayanan kepada setiap masyarakat dari berbagai golongan dengan tujuan untuk meningkatkan kesadaran bahwa kepemimpinan yang ia emban merupakan amanah yang diperuntukkan kepada kesejehteraan dan melayani masyarakat bawahannya sebagai pola bimbingan dan membawa kepada kebaikan. Dan juga sebagai Guardian adalah penjaga pelindung masyarakat dalam rangka melawan penindasan dan tirani untuk meningkatkan kesadaran dan ketaqwaan kepada Allah 稿 dan menjunjung nilai-nilai keadilan bagi segenap masyarakat. (Beekun \& Badawi, 1999)

Untuk mewujudkan seseorang menjadi pemimpin yang ideal dibutuhkan syarat-syarat yang tergambarkan dalam bentuk ciri-ciri yang termiliki. Adapun ciri-ciri untuk menjadi seorang pemimpin (Irham, 2013). Memiliki kompetensi yang sesuai dengan zamannya. Artinya, kemampuan yang dimiliki sesuai untuk diterapkan dan diakui oleh para ahli. Memahami setiap permasalahan secara mendalam dan mampu memberikan solusi dalam sebuah keputusan. Mampu menerapkan konsep "the right man and the right place" secara tepat dan baik. Pemimpin adalah handal dalam memposisikan setiap potensi sesuai dengan kadar kemampuan seseorang dan tempat.

Untuk memahami lebih dalam tentang ciri-ciri pemimpin yang terlihat dari sifat-sifat pemimpin yang dikemukakan oleh George R. Terry (Kartono, 2010) Energi yaitu mempunyai kekuatan mental dan fisik. Stabilitas emosi yaitu seorang pemimpin tidak boleh berprasangka buruk terhadap bawahannya, ia tidak boleh cepat marah dan percaya pada diri sendiri harus cukup sabar. Human relationship yaitu mempunyai pengetahuan tentang hubungan manusia. Personal motivation yaitu keinginan menjadi pemimpin harus besar, dan dapat memotivasi diri sendiri. Communication skill yaitu mempunyai kecakapan untuk berkomunikasi. Teaching skill yaitu mempunyai kecakapan untuk mengajarkan, 
menjelaskan dan mengembangkan bawahannya. Social skill yaitu mempunyai keahlian di bidang sosial, supaya terjamin kepercayaan dan kesetiaan bawahannya. Ia harus suka menolong, senang jika bawahannya maju, peramah serta mampu dalam pergaulan. Technical competent yaitu mempunyai kecakapan menganalisis, merencanakan, mengorganisasi, mendelegasikan wewenang, mengambil keputusan dan mampu menyusun konsep.

Karakteristik gaya kepemimpinan yang diambil dari beberapa tipe kepemimpinan sesuai karakter pemimpin. (Kahyo, 2005) Pemaksa, senang menghukum tidak suka memberi, memiliki pemikiran bahwa setiap orang malas dan harus dipaksa, tidak suka menerima umpan balik dari bawahannya. Pendobrak, mempunyai motivasi prestasi tinggi, melakukan dengan mandiri, tidak suka mendelegasikan tugas dan wewenang, tidak menaruh perhatian kepada sekitar, mempunyai standar mutu kerja yang tinggi, tidak memiliki sifat pemimpin yang baik. Penguasa, usul atau pendapat di ajukan secara halus, memberikan hukuman tetapi suka memberi penghargaan, suka mendengar umpan balik dari bawahan dan sekitar. Penyayang, suka memanjakan anggotannya, tidak punya rencana kerja, selalu memberi penghargaan, tidak mengatur pekerjaan sendiri. Demokrat mempunyai rencana kerja secara terperinci, menaruh perhatian kepada sekitar, suka menanyakan pendapat, suka memberi penghargaan tidak suka memberi. Pembina, menetapkan tujuan dengan jelas dan memberikan tantangan tetapi agak moderat, suka menerima dan memberikan umpan balik teperinci, memberi penghargaan tetapi juga memberikan hukuman, mendelegasikan wewenang dan memberikan bantuan kepada anggota atau bawahan, bawahan mempercayai dan menghormatinya.

Fungsi kepemimpinan secara operasional memiliki lima fungsi pokok. (Rivai, 2009) Pertama, Fungsi intruksi yaitu fungsi yang bersifat komunikasi satu arah yang memberikan pengaruh dalam perintah dan komunikatif dalam memutuskan perkara. Kedua, Fungsi konsultasi yaitu fungsi yang bersifat komunikasi dua arah dengan memberikan kesempatan kepada bawahan untuk memberikan saran, masukan dalam mengambil keputusan. Ketiga, Fungsi partisipasi yaitu fungsi yang bersifat bahwa pemimpin berusaha mengaktifkan orang yang dipimpin baik dalam ikut serta mengambil keputusan maupun dalam pelaksanaannya. Keempat, Fungsi delegasi yaitu fungsi yang bersifat memberikan pelimpahan wewenang untuk membuat/menetapkan putusan baik melalui persetujuan atau tidak dari pimpinan. Kelima, Fungsi pengendalian yaitu fungsi yang bersifat bahwa pemimpin yang sukses 
mampu mengatur aktivitas anggotanya secara terarah dan mendalam sehingga tercapainya tujuan.

Kepemimpinan sesuai dengan tatanan Al-Qur'an dan Al Hadits dalam mengelola organisasi (Shoni R. A, 2012) dengan memiliki nilai-nilai prinsip tauhid yang merupakan nilai dasar dalam mengelola kepemimpinan Islam sebagai nilai primer dalam mengelola amanah yang diberikan Allah kepada manusia dengan pengabdian penuh dengan totalitas

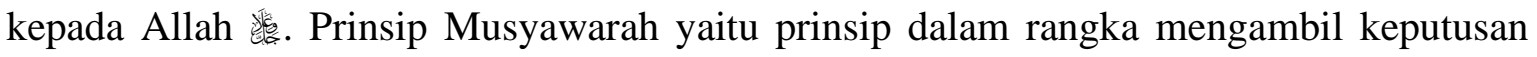
yang dilakukan oleh orang memiliki wawasan pengetahuan dalam permasalahan. Prinsip kebebasan berpikir yaitu pemimpin yang memberikan ruang dan kesempatan kepada setiap anggotanya dalam menyatakan pendapat dalam koridor yang membangun diskusi dalam menghadapi persoalan. Prinsip keadilan yaitu Seorang pemimpin yang menerapkan dengan tidak berat diantara satu sisi dan tidak memihak kepada siapapun berdasarkan persamaan dan kesusaian.

\section{Tazkiyah Al Nafs}

Tazkiyah dalam pengertian bahasa bermakna pembersihan (tathir), pertumbuhan dan perbaikan (al-islah). Dengan demikian tazkiyah al nafs adalah suatu cara untuk membersihkan dan memberikan perlakuan yang memiliki metode dan teknik-teknik, sifatsifat yang berasal dari syariat, dan hasil-hasil serta kesan-kesannya diaplikasikan dalam tingkah laku dalam rangka menggapai keridhaan Allah baik hubungan dengan makhluk, dan dalam usaha mengendalikan diri menurut perintah Allah 憩. Tazkiyah dibagi kepada tiga komponen penting yaitu tazkiyah al-nafs (penjernihan jiwa), tazkiyah al-aql (penjernihan akal) dan tazkiyah al-Jism (penjernihan tubuh/badan). (Langgulung, 2002)

Tazkiyah al nafs adalah suatu cara bagi seorang hamba dalam rangka memberika penyucian jiwa dengan melakukan peribadatan sesuai dengan tuntunan syariat sehingga jiwa terlindungi dari kotoran yang terdapat dalam diri manusia seperti sifat tercela dengan menanamkan sifat-sifat terpuji yang diaplikasikan dalam kehidupan sehari-hari dalam rangka menggapai keridhaan Allah 䖪.

Ibnu Taimiyah menjelaskan bahwa at tazkiyah adalah menjadikan suci baik zatnya maupuk keyakinan dan fisiknya. Allah 䁙 mensifati orang-orang yang menyucikan jiwa itu dengan keberuntungan dan mensifati orang-orang yang mengotorinya dengan kerugian. Ibnu Jarir At Thabari menjelaskan bahwa orang-orang yang beruntung yaitu yang Allah 
s serikan jiwanya dari kemaksiatan dan kekufuran serta memperbaikinya dengan amal saleh. (Thabari, 1420)

Untuk mendapatkan keberuntungan tersebut dari Allah 霠 Ibnu Katsir menjelaskan bahwa manusia harus menempuh jalan yaitu mentaati Allah 猺, membersihkan jiwanya dari akhlak tercela serta membersihkan jiwa dari berbagai hal yang hina. (Imam Imamudiin Ibnu Katsir, 1420)

Ibn Katsir mengungkapkan tentang makna Tazkiyah yaitu bahwa Ali bin Abi Thalhah menceritakan dari Ibn Abbas bahwa makna Tazkiyah disini adalah "ketaatan kepada Allah 㴗 dan tulus ikhlas karenanya”.(Ghofar M. Abdul et.al, 2010)

Said Hawa mendefiniskan Tazkiyah sebagai penyucian (Tathahur) jiwa dari segala penyakit, merealisasikan (Tahaqquq) berbagai maqam padanya dan menjadikan (Tahalluq) asma dan sifat-Nya sebagai akhlak. (Hawa, 1998)

Buya Hamka menggungkapkan bahwa lawan dari kata penyucian adalah mengotorinya. Jikalau jasmani yang dikotori mungkin dapat disucikan dengan thaharah berwudhu namun bagi orang yang mengotori jiwa dengan kesyirikan atau dendam atau benci atau kufur atau munafik. (Yunan M. Yusuf, 2010) Maka harus dibersihkan dengan cara melaksanakan segala perintahnya baik shalat fardhu, puasa, sedekah, zakat, tadabbur, tafakur, zikir dll.

Tazkiyah merupakan kunci untuk meluruskan suluk (perilaku, Akhlak). Akhlak yang mulia yang terpancarkan dari hati yang suci merupakan misi yang dibawa oleh para nabi termasuk nabi Muhammad 槄 sebagai pembawa risalah yang mengeluarkan manusia dari zaman kegelapan atau kesesatan ke zaman yang terang benderang yaitu petunjuk Allah dan kebenaran dengan wahyu illahi yaitu Al-Qur'an. (Ghofar M. Abdul et.al, 2010)

Kata al nafs memiliki arti yaitu jiwa menurut Ibn Manzur (W. 630 H). Namun selain itu, Ibn Ishaq mengatakan bahwa an nafs memiliki dua pengertian yaitu nafas atau nyawa dan diri atau hakikat diri. Selain itu juga Ibn Abbas mengatakan bahwa manusia memiliki dua unsur an nafs yaitu an nafs 'aqliyah yang bisa membedakan sesuatu dan an nafs ar ruhiyah yang menjadi unsur kehidupan.

Dalam filsafat Islam kata an nafs memiliki arti jiwa. Pengertian ini merupakan pengaruh langsung dari Aristoteles (384-322 SM.) yang menyatakan bahwa jiwa dibagi dua bagian yaitu irasional dan rasional. Namun penyataan ini dibantahkan oleh Ibn Shina yang menyebutkan bahwa manusia memiliki tiga bagian jiwa diantaranya adalah an nafsu al 
nabatiyah, an nafsu al hawaniyah, dan an nafsu al insaniyah yang mana pada an nafsu al insaniyah mempunyai daya pikir yang disebut 'aqla. (Baharuddin, 2007)

Al Nafs merupakan salah satu elemen yang sangat penting dalam kehidupan manusia karenanya ia menjadi elemen dasar psikis manusia. Elemen yang merupakan bagian fundamental yang menjadi bagian pokok dari sesuatu. Di dalam an nafs tersebutlah tersimpan beberapa dimensi jiwa manusia diantaranya adalah al aql, al qalb, al ruh, al fitrah. Namun selain itu pula an nafs juga mampu menampung dimensi taqwa yang bernilai postif dan fujur yang bernilai negatif. Allah berfirman dalam surat As Syams [91] ayat 7-8:

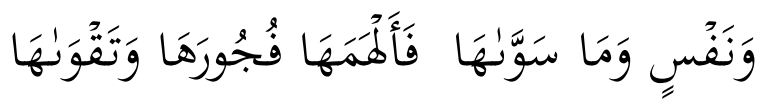

"Dan jiwa serta penyempurnaannya (ciptaannya) maka Allah mengilhamkan kepada jiwa itu (jalan) kefasikan dan ketakwaannya".

Menurut para sufi makna jiwa dijabarkan secara kedudukan atau posisi yang memiliki arti bahwa jiwa adalah dimensi manusia yang berada diantara ruh dan an nafs. Yang mana ruh membawa cahaya (nur) dan an nafs membawa kegelapan (zulm) pejuangan spiritual dilakukan untuk mengangkat jiwa menuju ruh dan melawan kecenderungan an nafs yang rendah. Sehingga dalam dunia tasawuf memahami hubungan psikis manusia dengan hubungan konflik. Konflik antara ruh dan an nafs diantara konflik tersebut muncul an nafs yaitu makna yang merangkum antara kekuatan marah dan syahwat dalam diri manusia yang menjadai dasar tumbuhnya segaa sifat-sifat tercela dalam diri manusia. (Ali Abdul Halim Mahmud, 2000)

Imam Al Ghazali mendefinisikan bahwa jiwa dibagi menjadi dua yaitu kekuatan hawa nafsu yang akan membawa kesenangan dan kenikmatan dunia secara materi yang digunakan untuk melestarikan kehidupan dan kekuatan petunjuk yang menjadi media dalam berkomunikasi kepada tuhan dengan memenuhi kebutuhan rohani dan memperbaikinya dengan amalan dunia dan akhirat. (Muhyani., Herawati. S., 2019)

Menurut harfiah kata jiwa adalah kalbu yang terealisasikan dalam perilaku yang disebut dengan perangai tingkah laku budi pekerti tabiat watak atau karakter serta akhlak. Al Ghazali menyatakan bahwa akhlak merupakan sifat yang terpatri dalam jiwa yang darinya lahir perbuatan-perbuatan dengan mudah dan tanpa memikirkan serta merenung terlebih dahulu. (Ali Abdul Halim Mahmud, 2000) Dengan demikian, akhlak merupakan cerminan dari kebersihan serta kesucian hati. 
Nafs (jiwa) pada diri manusia bersifat tidak stastis, tetapi nafs memliki pusat tenaga dan kekuatan yang terdiri dari sebagaiman berikut yang disebut tiga pusat kekuatan dalam nafs. Al-nafs al-ammarah yaitu kekuatan kesadaran tingkat rendah sebagai naluri dan nagsdu kebinatangan seperti makan, minum, tidur, kebutuhan seksualitas kerakusan dan emosi seperti marah, cinta, benci. Al-nafs al-lawwamah pada kekuatan ini nafs ini berkaitan dengan qalb, atau jenjang pertengahan kesadaran yang berkaitan dengan rasional atau tingkat hati nurani. Ruh adalah kekuatan Yang paling tinggi adalah jenjang ruh yang paling dekat kepada asal ilahi. (Hasan Langgulung, 1992)

Tazkiyah al nafs adalah suatu cara yang dilakukan oleh seorang hamba untuk menyucikan diri dari segala pebuatan yang mengandung kesyirikan dan derivatnya seperti sifat-sifat tercela di antaranya adalah riya, sombong ujub yang kemudian ditumbuhkan dalamnya secara internalisasi nilai-nilai ketauhidan dalam diri yang terlihat dari sifat-sifat terpuji sperti sabar, zuhud, tawakal dan lain-lain. (Lajnah Pentashihan Mushaf Al-Qur'an Kemenag RI, 2010)

Tazkiyah al nafs adalah suatu cara untuk menyucikan diri dari berbagai kecenderungan keburukan dan dosa dan mengembangkan fitrah yang baik didalamnya yang dapat menengakan istiqamahnay guna mencapai derajat ihsan. Cara yang dilakukan adalah dengan memberikan ruang secara dominan untuk sifat-sifat kebaikan dalam dirinya dan berusaha menekan dan mengekang dengan sekuatnya dari sifat buruk yang ada dalam dirinya serta mengarahkan kepada segala yag dilakukan untuk mendapat keridhaan Allah 踩. (Anas Ahmad Karzon, 2016)

Tazkiyah al nafs adalah suatu konsep untuk membatasi problem spiritual dan krisis kejiwaan denagn cara membebaskan jiwa-jiwa dari hawa nafsu dan kehinaan dalam mengikuit hawa nafsu dengan memberikan pendidikan untuk jasmani sebagai kebutuhan untuk kemaslahatan badan dan pendidikan ruhani untuk kemaslahatan jiwa (Akhmad Alim, 2018).

Tazkiyah dalam pengertian bahasa bermakna pembersihan (tathir), pertumbuhan dan perbaikan (al-islah). Dengan demikian tazkiyah al nafs adalah suatu cara untuk membersihkan dan memberikan perlakuan yang memiliki metode dan teknik-teknik, sifatsifat yang berasal dari syariat, dan hasil-hasil serta kesan-kesannya diaplikasikan dalam tingkah laku dalam rangka menggapai keridhaan Allah baik hubungan dengan makhluk, dan dalam usaha mengendalikan diri menurut perintah Allah 褢. Tazkiyah dibagi kepada tiga 
komponen penting yaitu tazkiyah al-nafs (penjernihan jiwa), tazkiyah al-aql (penjernihan akal) dan tazkiyah al-Jism (penjernihan tubuh/badan). (Hasan Langgulung, 2002)

Dari pemaparan diatas maka dapat difahami bahwa tazkiyah al nafs adalah suatu cara bagi seorang hamba dalam rangka memberika penyucian jiwa dengan melakukan peribadatan sesuai dengan tuntunan syariat sehingga jiwa terlindungi dari kotoran yang terdapat dalam diri manusia seperti sifat tercela dengan menanamkan sifat-sifat terpuji yang diaplikasikan dalam kehidupan sehari-hari dalam rangka menggapai keridhaan Allah

Metode dalam memberikan tazkiyah al nafs dalam diri seseorang sebagai suatu bentuk yang akan dilakukan oleh seorang hamba dengan menggunakan Ilmu yaitu sang penentu untuk membedakan antara keraguan dan keyakinan. Tadzakur yaitu suatu gambaran dan pengingat seseorang berdasarkan atas ilmu yang dimilikinya sebagai upaya untuk pertahanan dalam diri dari sifat yang mampu mengotori jiwa. Riyadhah adalah suatu aplikasi yang diterapkan dalam kehidupan sehari-hari sebagai bentuk pengabdian kepada Allah yang dilakukan secara terus menerus dan keistiqamahan yang berfungsi untuk menyucikan jiwa dengan penanaman kebenaran baik dalam perbuatan, perkataan dan keinginan dan menyakini yang membawa kebenaran.

lam rangka mewujudkan tazkiyah an nafs Syaikh Al Islam Ibn Taimiyah memberikan beberapa konsep dalam mewujudkan jiwa yang tenang dan suci. Iman Dan Tauhid. Yaitu Keimanan kepada Allah ${ }^{5}$ dan kemurnian tauhid yang terpancarkan di dalam diri seseorang merupakan bukti nyata bahwa akan kesucian jiwanya sebagaimana yang didapati oleh para

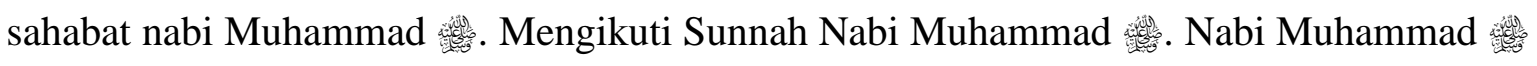
merupakan penutup para nabi yang diutus kepada seluruh umat manusia yang diturunkan di tanah arab yang mana pada saat itu kehidupan manusia berada dalam kegelapan dari segi keimanan dimana hidupnya paganisme. Tidaklah dikatakan beriman barang siapa yang mengingkari keimanan kepada nabi Muhammad 䌑 karena beriman kepada nabi Muhammad 鼬. merupakan diterimanya keimanan kepada Allah sebagaimana yang terucap dan tertulis pada dua kalimat syahadat. Mengerjakan segala kewajiban dan perintah agama. Sesungguhnya kewajiban di dalam agama Islam baik yang berupa kewajiban, rukun-rukun, larangan, perintah sunnah serta apa-apa yang menjadikan kecintaan dalam agama Islam membawa diri seseorang tersebut dalam rangka menyucikan diri baik jasmani maupun rohani serta menyinari bagian inti dalam diri seseorang. 
Kewajiban yang dilakukan pada setiap hamba memiliki pengaruh yang sangat besar dalam menyucikan diri jika dikerjakan dan diamalkan dengan kesungguhan hati tidak hanya dalam bentuk verbal semata. Diantara kewajiban yang dikerjakan adalah shalat, puasa, dzikir, membaca Al-Qur'an, zakat, haji dan lain-lain. (Ibn Taimiyah, 1994)

Hujjatul Islam Imam Al Ghazali dalam menjelaskan tentang tazkiyah al nafs meliputi tazkiyah al qalb, tazkiyah al fikrah, tazkiyah al aqidah, tazkiyah al ubudiyah, tazkiyah al ibadah, tazkiyah al akhlak, dan tazkiyah as sir. (A.F. Jaelani, 1997)

Dalam menopang kehidupan didalam pendidikan ruhaniyah dalam diri manusia dintaranya Melakukan berbagai zikir, wirid, dan do'a-do'a dengan memperhatikan adabadabnya. Melakukan riyadah dalam pengamalan berupa melaksanakan kewajiban dengan sepebuh hati, mengamalkan amalan sunnah, mengerjakan amar maruf nahi mungkar, berusaha mencapai derajat ihsan, melaksanakan berbagai aktivitas dalam dakwah di jalan Allah mengadakan pertemuan amalan untuk ibadah, dan menziarahi kubur. Menanamkan dalam diri untuk berkomitmen dalam menyesuaikan diri dengan spesifikasi orang-orang yang selalu memiliki perasaan kuat akan keberadaan Allah merasakan

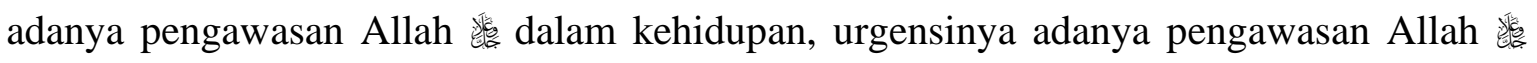
dalam diri manusia, berusaha mendekatkan diri dengan mengerjakan amalah sunnah (nawafil), mendekati Allah dengan mencintai manusia dan kebaikan bagi mereka, mencintai Allah dan percaya kepada-Nya atas kebajikan dan pengabulan setiap hajat dan do'a serta rala atas penetapan qadha dan qadar Allah 䛗.(Muslih Muhammad, 2002)

Imam Ibnu Qayyim menyebutkan dalam konsep tazkiyah al nafs dalam rangka memberikan pendidikan bagi jiwa seseorang yang dilakukan melalui latihan untuk merealisasikan kesucian batin dalam upaya mendekatkan diri kepada Allah dengan membagi dalam tiga metodologi.

Takhliyah adalah sebuah usaha seseorang untuk membersihkan diri dari hawa nafsu yang mengikat dalam diri agar terhindar dari tipu daya yang licik yang mampu menggoda bagi diri seseorang diantaranya adalah fitnah syubhat dan syahwat.

Tahliyah adalah proses pengisian dan penghias jiwa dengan amalan-amalan yang baik dan sifat-sifat terpuji bagi diri seseorang yang dilalui dengan beberapa tahapan diantaranya mujahadah, taubat nasuhah, sabar, muhsabah, tafakkur, khauf, raja', mahabbah.

Tahqiq ubudiyah adalah suatu proses untuk mengimplementasikan dari nilai ibadah yang dikerjakan oleh seseorang yang diaplikasikan dikehidupan sehari-sehari dalam rangka 
penghambaan kepada Allah sebagai aplikasi dari ilmu yang dimiliki dengan amal yang diwujudkan dalam kehidupan. Muslih Muhammad, 2002)

Syaikh Al Harits bin Asad Al Muhasibi memberikan metode dalam rangka tazkiyah al nafs yang dilakukan dalam diri seseorang yaitu:

Wiqayah yaitu pencegahan dari sifat yang dapat mengotorinya diantara sifatnya adalah sadar akan kelalaian yang terdapat dalam dirinya kembalinya manusia ke jalan Allah akan kesadaran yang muncul dalam dirinya (at tawbah), mengenali dan kemampuan untuk membedakan antara kebaikan dan keburukan (ma'rifat al khyar wal al ashr), menyadari akan keberadaan dan pengetahuan Allah dalam setiap tingkah laku (al muraqabah), merenungi setiap perbuatannya dan berpikir untuk menjaga dirinya dari perbuatan hawa nafsu (al muhasabah) dan mengetahui strategi nafsu dan godaan syaitan (ma'rifah khida al $n a f s)$.

Tanmiyah yaitu penerapan atau pengamalan dari sifat-sifat terpuji yang dilakukan dalam kehidupan sehari-hari dengan melaksanakan amalan-amalan sunah (al ibadah wal ad dzkir), meninggalkan kenikmatan dunia yang akan membawa kemurkaan Allah (al zuhd), menanamkan rasa kecukupan akan kemampuan yang dicapai (al qana'ah), membangun kecintaan kepada Allah (al mahabbah), memunculkan rasa takut kepada kemurkaan Allah dengan menjalankan perintahnya dan menjauhi larangannya (al khauf).

'Ilaj yaitu perawatan atau pengobatan dari sifat-sifat yang terdapat dalam diri seseorang seperti perawatan atas pengobatan sifat riya, ujub, kesombongan, hasad dan lalai. (Dardaa Mohamad, Hanin Hamjah, \& Irdha Mokhtar, 2017)

Dalam menopang kehidupan didalam pendidikan ruhaniyah dalam diri manusia maka sebaiknya setiap individu manusia Melakukan berbagai zikir, wirid, dan do'a-do'a dengan memperhatikan adab-adabnya. Melakukan riyadah dalam pengamalan berupa melaksanakan kewajiban dengan sepebuh hati, mengamalkan amalan sunnah, mengerjakan amar maruf nahi mungkar, berusaha mencapai derajat ihsan, melaksanakan berbagai aktivitas dalam dakwah di jalan Allah 蹈, mengadakan pertemuan amalan untuk ibadah, dan menziarahi kubur.

Menanamkan dalam diri untuk berkomitmen dalam menyesuaikan diri dengan spesifikasi orang-orang yang selalu memiliki perasaan kuat akan keberadaan Allah 数, merasakan adanya pengawasan Allah dalam kehidupan, urgensinya adanya pengawasan Allah dalam diri manusia, berusaha mendekatkan diri dengan mengerjakan amalah 
sunnah (nawafil), mendekati Allah dengan mencintai manusia dan kebaikan bagi mereka, mencintai Allah dan percaya kepada-Nya atas kebajikan dan pengabulan setiap hajat dan do'a serta rala atas penetapan qadha dan qadar Allah (Muslih Muhammad, 2002)

Pelaksanaan tazkiyah al nafs dalam diri seseorang dapat dilakukan dan dicapai dengan berbagai bentuk peribadatan yang dilakukan oleh seseorang hamba menjaga nilai Tauhid yang merupakan pangkal dan dasar utama dalam keimanan manusia sehingga mampu menghilangkan rasa sombong, riya, ujub, dengki, hasad dan nilai tauhid mampu menumbuhkan buah tauhid seperti sabar, ikhlas, jujur, dan lain sebagainya.

Shalat merupakan pilar dan keimanan yang menanamkan makna penghambaan

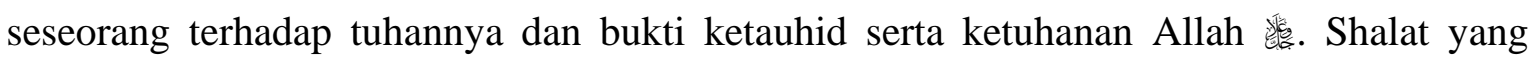
ditegakan oleh manusia akan memberikan efek untuk menghilangkan sifat-sifat tercela seperti ujub, riya, sombong, seluruh perkara yang keji dan mungkar dengan pelaksanaan menjaga syarat, rukun dan sunahnya yang dilakukan dengan adab lahir dan batin.

Zakat dan Infak adalah suatu peribadatan yang dijika dlilakukan akan berfungsi untuk menyucikan baik harta maupun jiwa dari sifat kekikiran dan akan bersifat bertumbuh.

Puasa adalah suatu peribadatan yang berfungsi untuk mengekang hawa nafsu dalam diri seseorang sehingga mampu memberikan pelatihan penempahan bagi jiwa agar selalu diberi kesabaran.

Haji adalah pembiasan jiwa untuk melakukan hal hal yang kondusif untuk menyucikan jiwa seperti tawakal kepada Allah 踩, mencurahkan segenap kemampuan dan harta kepada jalan Allah, saling tolong menolong, serta melaksanakan syiar-syiar ketundukan kepada Allah 践.

Membaca Al-Qur'an dapat menyucikan jiwa, memperoleh keilmuan pengetahuan yang berisikan akan perintah dan larangan dan mampu membangkitkan berbagai nilai virtual yang ingin dicapai dengan memperhatikan adab-adab dalam membaca dan mentadaburinya.

Zikir dan Tafakur yaitu suatu peribadatan yang berfungis untuk selalu mengingat akan keberadaan Allah sehingga dapat melindungi seseorang untuk berbuat kemaksiatan dan bertafakur atas kekuasaan dan penciptaannya Allah 数.

Mengingat kematian dapat membuat jiwa menjadi suci karena dengannya jiwa akan lunak dan terbebas dari keangkuhan dan menyadari akan kehidupan di dunia hanya sementara. 
Meninggalkan apa yang diharamkan sebab jiwa akan suci jika seseorang mampu untuk meninggalkan segala apa yang telah diharamkan oleh Allah sehingga hati akan terlepas dari segala yang dapat mengotorinya.

Muhasabah yaitu melakukan intropeksi diri dalam menjalani kehidupan dengan berpikir sebelum melaksanakan sesuatu dan semangat dalam melakukannya dan merenungkan segala perbuatan yang telah dikerjakan.

Amar ma'ruf nahi mungkar dan jihad adalah seseorang yang ingin jiwanya bersih dari segala kotoran sebaiknya mengerjakan amar ma'ruf nahi mungkar, bertaqwa, berijihad dan beramal saleh di jalan Allah agar mendapatkan keberuntungan dalam jiwa dan mampu menghilangkan segala kotoran dalam jiwa seseorang. (Lajnah Pentashihan Mushaf AlQur'an Kemenag RI, 2010)

\section{METODE}

\section{Desain Penelitian}

Pada penulisan ini sang penulis menggunakan metode penelitian tindakan (action research) suatu tindakan yang dilakukan oleh seorang peneliti dalam rangka mengukur, menginvestigasi atau mengevaluasi suatu tindakan yang diberikan kepada seseorang yang dilakukan oleh para praktisi di berbagai tempat sebab penelitian ini merupakan penelitian yang dilakukan secara professional.

ungkapan ini sesuai dengan teori yang disampaikan oleh yaitu "Action research is a from of enquiry that enables practitioners everywhere to invitigate an evaluate theirs work". (Jean McNiff and Jack Whitehed, 2006)

Analisis pada penelitian ini analisis yang berjenis kualitatif yaitu suatu bentuk analisis penelitian yang bermaksud untuk memahami fenomena tentang apa yang dialami oleh subjek penelitian seperti prilaku, persepsi, motivasi, tindakan atau kasus yang dikaji dan lain-lain. (Lexy J. Moleong, 2011)

Bahan yang dianalisa berupa program, kegiatan dan aktivitas atau loncatan waktu dan tempat individu. Jenis penelitian ini bersifat analisis isi atau dokumen yaitu memusatkan kajian pada analisis dan interprestasi bahan atau materi yang direkam baik cetak atau tulis untuk mempelajari prilaku manusia. (Margono, 2013)

\section{PEMBAHASAN}


Model pendidikan kepemimpinan berbasis tazkiyah al nafs merupakan suatu acuan, pola dasar, contoh dan role model suatu pendidikan yang diberikan oleh pondok pesantren La Tansa.

Pondok Pesantren La Tansa merupakan lembaga pendidikan yang mempersiapkan sumber daya manusia muslim yang memiliki ilmu pengetahuan yang seimbang secara bidimenasional sehingga mampu mengimplementasikannya dalam kehidupan yang ihsan baik di dunia maupun di akhirat.

Dalam rangka melahirkan para kader-kader pemimpin umat yang bermutu dan unggul dengan penanaman tazkiyah al nafs dalam diri santri yang dilaksanakan melalui kegiatankegiatan pondok pesantren selama 24 jam yang tersistem dan terstruktur.

Tazkiyah al nafs yang diberikan oleh pondok pesantren La Tansa merupakan sebuah "soft clinic" yang dilakukan oleh setiap sektor masyarakat yang tertanam dalam nilai-nilai panca jiwa yaitu keikhlasan, kesederhanaan, ukhuwah islamiyah, berdikari dan moto pondok yaitu berbudi luhur, berbadan sehat, berpengetahuan luas dan berpikir bebas serta penanaman nilai-nilai yang terdapat dalam landasan falsafah pondok sebagai landasan dan dasar utama dalam melaksanakan setiap kegiatan pondok pesantren.

Selain penanaman nilai-nilai panca jiwa dan moto pondok dalam diri santri dalam rangka mengimplementasikan tazkiyah al nafs tersistem dengan mengaplikasikan pembekalan, pelatihan dan pendidikan dasar dalam mengembang suatu kepemimpinan yang dilakukan oleh pondok pesantren La Tansa.

Pendidikan kepemimpinan ini dimulai dengan pembekalan pra santri pada saat kedatangan sanri baru mengenai tata cara salat kemudian tahsin bacaan Al Qur'an yang kemudian menjalankan kepengurusan dalam rayonisasi dan keorganisasian dalam OSIS maupun kepramukaan yang telah mendapatkan pelatihan melalui "up grading" kepengurusan dan kursus mahir dasar untuk kepengurusan pramuka baik putra maupun putri.

Model pendidikan kepemimpinan yang berbasis tazkiyah al nafs yang diterapkan melalui kegiatan-kegiatan, program dan sunah pondok yang dilaksanakan melalui rutinitas yang tersusun secara sistematis dan terstruktur di dalamnya meliput persiapan untuk menciptakan generasi yang siap memimpin dalam ruang lingkup masyarakat mikro dalam miniatur kehidupan diantara perencanaan yang dilaksanakan tentang pemberian pelatihan dasar kepada setiap generasi/angkatan untuk menjadi para pemimpin, menjadi pengurus kamar di setiap rayon untuk mengimplematasikan kepemimpinan dalam lingkup kecil yaitu 
asrama, mendapatkan pelatihan menjadi pengajar halaqah Al-Qur' an dalam kegiatan metode Iqra.

Kegiatan 'up grading” sebagai pembekalan dalam menjalani roda kepengurusan, mengikuti dalam kegiatan mahir dasar tentang kepramukaan serta mendapatkan pelatihan dalam perihal peribadatan, menerapkan pemusyaratan dalam menjalani keorganisasian yang diaplikasikan dalam kegiatan musyawarah kerja pada awal tahun kepengurusan yang akan menghasilkan standar operasional kerja yang disebut dengan program kerja OSIS maupun DKG.

Pelaksanaan model pendidikan kepemimpinan berbasis tazkiyah al nafs di pondok pesantren La Tansa merupakan suatu aplikatif yang diterapkan melalui kegiatan-kegiatan yang berpedoman atas panca jiwa pondok dan moto pondok sebagai landasan utama baik yang bersifat peribadatan maupun kegiatan hari.

Diantara pelaksanaan tazkiyah al nafs yaitu kegiatan belajar mengajar yang dilaksanakan sebagai wadah untuk mentransformasikan nilai-niali keilmuan sebagai dasar penentuan dalam membedakan antara yang hak dan batil dalam menjalani proses miniatur kehidupan.

Aplikasi pendidikan kepemimpinan yang diberikan melalui perjalanan kepengurusan baik yang dilaksanakan dalam rayonisasi maupun dalam masyarakat mikro yaitu kepengurusan OSIS dan DKG untuk menjamin terselenggaranya kegiatan-kegiatan pondok pesantren secara stabil yang diwujudkan dalam peribadatan yang pokok maupun yang sunah dalam syariat seperti salat berjamaah, zikir setelah salat, halaqah Al-Qur'an, puasa senin kamis, salat duha dan tahajud terjadwal, zakat dan sadaqah dan lain-lainnya.

Kegiatan yang dilakukan oleh para santri yang diatur secara sistematis dan terstruktur ini merupakan wujud tadzkirah sebagai suatu gambaran yang hadir dalam hati siswa seseorang yang berdasarkan atas pengetahuan yang dimilikinya sebagai upaya untuk mepertahankan dalam diri dari sifat-sifat tercela seperti sombong, hasad, pemarah, menjadi pemimpin yang curang, ghibah, mengolok-olok, bakhil dan lain sebagainya.

Nilai peribadatan yang dilaksanakan sebagai bentuk riyadhah yaitu suatu aplikasi yang diterapkan dalam kehidupan sehari-hari sebagai bentuk pengabdian kepada Allah $\square$ yang dilakukan secara terus menerus dan keistiqamahan yang berfungsi untuk menyucikan jiwa dengan penanaman kebenaran baik dalam perbuatan, perkataan dan keinginan dan menyakini yang membawa kebenaran. 
Pengistilaan kata tazkiyah al nafs yang diaplikasikan dalam peribadatan yang dilaksanakan baik yang bersifat mahdoh atau goiru mahdoh oleh setiap individu dalam miniatur kehidupan bermasyarakat mikro ini tidak familiar namun secara konsep dan dasar dari tazkiyah yang merupakan menjadi hidden kurikulum sebagai nilai kelebihan dari suatu model pendidikan yang diberikan oleh pondok pesantren yang tertanamkan sejak dini sejak bangun tidur sampai tidur kembali dalam waktu 24 jam.

Sehingga dari tazkiyah al nafs yang aplikatif sebagai Ilaj yaitu perawatan atau pengobatan dari sifat-sifat yang terdapat dalam diri seseorang seperti pengobatan sifat riya, ujub, kesombongan, hasad dan lalai, dan menanamkan sifat-sifat terpuji dalam diri santri dengan terciptanya santri yang ikhlas, sederhana, mampu bergaul sesama teman dalam rangka ukhwah islamiyah, mengantungkan diri pada diri sendiri/ berdikari, santri yang memiliki kebebasan dari sifat-sifat belenggu untuk beriktiar dan berbuat kebaikan sehingga melahirkan generasi pemimpin yang memiliki budi yag luhur, jasmani yang sehat, pengetahuan yang luas, dan memiliki pemikiran yang bebas dalam menciptakan kemanfaatan untuk keummatan.

Hasil dari pelaksanaan kepemimpinan berbasis tazkiyah al nafs di pondok pesantren La Tansa untuk melahirkan generasi penerus bangsa dalam hal menghidupkan jiwa para pemimpin yang berlandasan dalam kekuatan jasmani dan jiwa serta inteletualikitas yang dilaksanakan dalam suatu program yang bersifat sistematis dan terstruktur dengan demikian terlahirkan para generasi pemimpin yang memliki kemampuan baik secara intelektual, jasmani dan berakhlakul karimah.

Hasil jangka pendek yang diterapkan melalui pendidikan kepemimpinan berbasis tazkiyah al nafs ini suatu model yang diberikan kepada setiap santri sebagai wadah dalam pembentukan jiwa-jiwa untuk menjadi pemimpin yang berkemampuan dalam memimpin dirinya sehingga mampu menerapkan dalam masyarakat makro.

Sebagai batasan problem spiritual dan krisis kejiwaan dengan cara membebaskan jiwajiwa dari hawa nafsu dan kehinaan dalam mengikuti hawa nafsu dengan memberikan pendidikan untuk jasmani sebagai kebutuhan untuk kemaslahatan badan dan pendidikan ruhani untuk kemaslahatan jiwa sehingga mampu menjadi pemimpin yang menjadikan dirinya servant yang diaplikasikan dalam melaksanakan amanah yang diemban dalam kepengurusan guna menciptakan bimbingan, arahan untuk kesejahteraan dan kenyamanan bawahannya yang diatur dalam pola asah asih dan asuh dan juga menjadi pemimpin yang 
guardian dengan mengaplikasikan dalam kesadaran diri sebagai pembimbing bagi adik-adik kelasnya dan menerapkan nilai-ilai keadilan bagi segenap masyarakat mikro.

Hasil jangka panjang dari model pendidikan kepemimpinan berbasis tazkiyah al nafs di pondok pesantren La Tansa untuk menciptakan suatu pola dasar dalam sumbangsih pendidikan yang diberikan bernuansa atas kepemimpinan sehingga mampu melahirkan generasi yang menjadi pemimpin yang "khairul umah" dengan mampu memberikan kemaslahatan dan kemanfaatan yang berahlakul karimah kepada umat yang telah siap secara personal dan memiliki kemampuan secara intelektual, jasmani dan rohani sehingga mampu menjadi insan manusia yang bermanfaat yang mampu menjalankan kepemimpinan atas dasar kesucian jiwa dan menegakan kebaikan dalam kehidupan dan mencegah dari perbuatan kemungkaran dengan berlandaskan atas nilai-nilai keimanan yang kuat.

Allah berfirman dalam surat Ali Imran (3) Ayat 110 yang berbunyi:

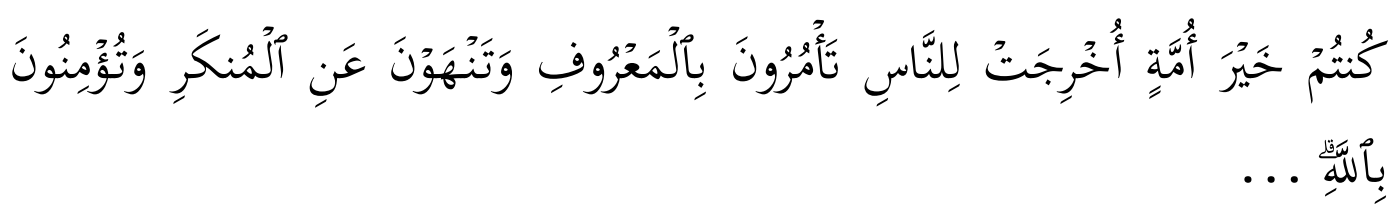

"Kamu adalah umat yang terbaik yang dilahirkan untuk manusia, menyuruh kepada yang ma'ruf, dan mencegah dari yang munkar, dan beriman kepada Allah..."

Evaluasi pendidikan kepemimpinan berbasis tazkiyah al nafs di pondok pesantren La Tansa dilaksanakan dalam waktu berskala yang diterapkan melalui pelaksanaan kegiatan, program-program kepesantrenan dimulai dari evaluasi pada saat pelaksanaan berlangsung dengan menanamkan nilai-nilai kesadaran bagi para elemen dalam masyarakat mikro baik didalam menjalani kehidupan sebagai pengurus kamar maupun organisasi OSIS sehingga mampu melahirkan para pemimpin yang berpikir solutif atas kesalahan dan kejanggalan yang terjadi di lapangan dengan didasari atas fakta lapangan yang terjadi.

Evaluasi berskala yang diterapkan juga dilaksanakan melalui evaluasi harian yang dilakukan pada setiap malam dengan memberikan pengarahan dan bimbingan kepada para pengurus baik osis maupun rayon dengan pengarahan yang diberikan dengan menggunakan metode yang diterapkan dapat memberikan pemahaman lebih kepada setiap pengurus dalam rangka menciptakan kehidupan asrama yang damai, aman dan sentosa serta nyaman.

Evaluasi pendidikan kepemimpinan berbasis tazkiyah al nafs yang diberikan oleh pondok pesantren kepada para pemimpin dalam kepengurusan OSIS dan DKG adalah dalam mengevaluasi mengenai program kerja yang telah disepakati dalam pelaksanaan dan monitoring yang dilakukan agar berjalannya organisasi dengan baik dan maksimal. Dengan 
demikian permasalahan dan segala kendala dalam menjalankan kepengurusan dapat teratasi dengan cepat, bijak dan tuntas. Evaluasi ini dilakukan pada setiap malam yang dilaporkan dalam kegaiatan lembar harian direktorat (LHD) yang diestafetkan dalam kepengurusan di setiap direktorat dalam bagan-bagan organisasi kepondokan.

Model pendidikan kepemimpinan berbasis tazkiyah al nafs ini menjadi suatu percontohan yang diberlakukan oleh lembaga pendidikan yaitu pondok pesantren la tansa dalam membuat sesuatu dengan tujuan sebagai dasar pola pendidikan yang melahirkan para generasi masa depan para pemimpin yang berkemampuan secara intelektual, jasmani dan rohani dengan berlandaskan atas kesucian jiwa yang sempurna sehingga mampu menciptakan kemaslahatan dan kemanfaatan untuk umat yang berakhlakul karimah sebab eksistensi utama bagi manusia adalah bagaimana jiwanya bukan raga dan badannya.

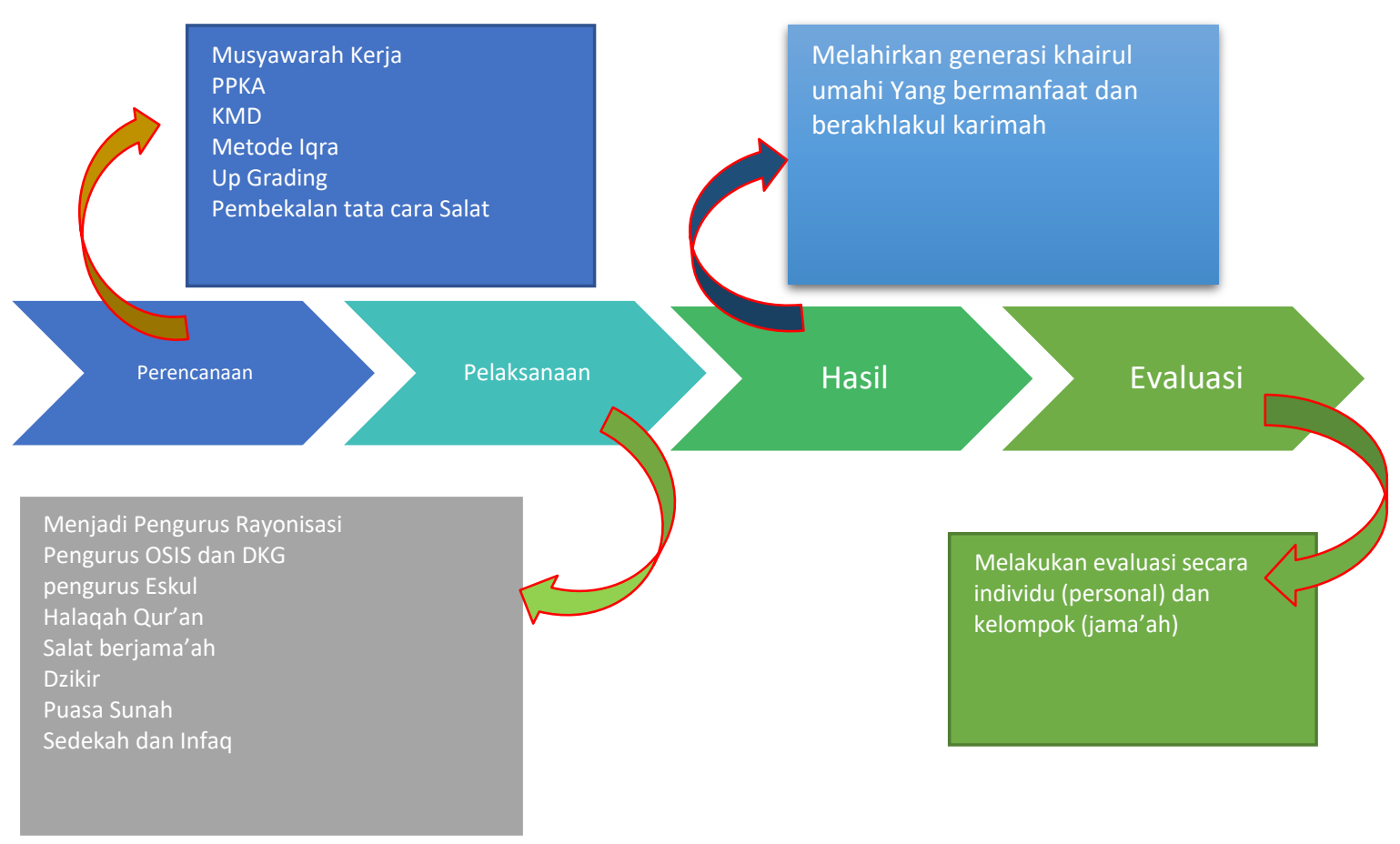

\section{KESIMPULAN}

Model pendidikan kepemimpinan berbasis tazkiyah al nafs di pondok pesantren La Tansa adalah suatu pendidikan percontohan mengenai penanaman nilai-nilai kepemimpinan yang diaplikasikan secara langsung melalui kegiatan-kegiatan, program, dan pelaksanaan ritual peribadatan yang telah di syariatkan melalui salat berjamaah, dzikir setalah salat, halaqah Al-Qur'an, berinfak, sedekah dan zakat serta penanaman sifat-sifat terpuji seperti kejujuran, 
kebenaran bertanggung jawab, amanah dan menjauhi dari sifat-sifat yang tercela seperti sombong, ujub, dusta, berbuat zalim.

Segala aktifitas, program dan kegiatan yang dilakukan dalam rangka model pendidikan kepemimpinan berbasis tazkiyah al nafs ini dilaksanakan dengan penuh kesadaran atas dasar panca jiwa yaitu keikhlasan, kesederhanaan, ukhuwah islamiyah, berdikari dan kebebasan serta moto pondok yaitu berbudi luhur, berbadan sehat, berpengetahuan luas dan berpikir bebas dengan beriorientasikan kepada kemaslahatan dan kemanfaatan bagi keummatan yang akan menjadikan diri sebagai "khairul umah".

Perencanaan yang dilaksanakan dengan mempersiapkan generasi penerus dengan memberikan pendidikan dan pelatihan seperti pengarahan mengenai panca jiwa dan moto pondok pada pekan Khutbatul Arsy, tata cara salat, tahsin qira'at Al-Qur'an pada masa pembekalan santri baru, kegiatan mahir dasar kepramukaan, up grading kepengurusan yang berisi pengarahan perjalanan kepengurusan dan motivasi kepengurusan, dan metode iqra sebagai pelatihan untuk menjadi pemimpin dan ketua halaqah Al-Qur'an yang dilakukan secara sistematis dan terstruktur dalam kegiatan dan sunah pondok.

Pelaksanaan pendidikan kepemimpinan berbasis tazkiyah al nafs di pondok pesantren diaplikasikan melalui kegiatan-kegiatan yang dilaksanakan oleh seluruh elemen masyarakat dengan mempraktekkan langsung dalam kegiatan yang berpanca jiwa dan bermoto pondok secara tersistem dan terstruktur yang bermuatan atas "jamiyatul ibadah" yang "mahdoh" atau "ghoiru mahdoh" seperti mengerjakan imam salat yang terjadwal, menjadi pengajar pada setiap kegiatan "halaqah Al-Qur'an”, menjadi mursyid atau ketua kelompok pada kegiatan kebahasaan seperti muhadatsah yang dilakukan pada dua kali dalam seminggu pada hari senin pagi dan jum'at pagi serta menjadi ketua muhadarah pada kelompokkelompok muhadarah, menjadi pengurus kamar dan OSIS, menjadi pembina kepramukaan. Semua kegiatan yang dilakukan dengan penuh keikhlasan tanpa pamrih dan memegang teguh serta bertanggung jawab, dan perwujudan dari peribadatan yang pokok maupun yang sunah dalam syariat seperti salat berjamaah, zikir setelah salat, halaqah Al-Qur'an, puasa senin kamis, salat duha dan tahajud terjadwal, zakat dan sadaqah dan lain-lainnya.

Hasil pendidikan kepemimpinan berbasis tazkiyah al nafs di pondok pesantren La Tansa adalah melahirkan generasi penerus sebagai pemimpin yang ideal dan bermutu dengan berlandaskan atas kemurnian tauhid dan kekuatan keimanan yang akan menjadi khairul umat yang akan membawa kemaslahatan dan kemanfaatan umat yang dihiasi dengan akhlak yang mulia. 
Evaluasi pendidikan kepemimpinan berbasis tazkiyah al nafs di pondok pesantren dilaksanakan secara berskala yaitu dengan penarpan tazkirah dan tabsyirah untuk mendapatkan hasil pendidikan kepemimpinan yang berlandaskan atas kebijakan dan kemampuan dengan memberikan pengarahan dan penanaman sifat-sifat terpuji yang berdasarkan atas kesadaran dari diri sendiri melalui sistem seperti pengarahan secara harian, mingguan, dan bulanan dengan pelaporan dan monitoring yang berpedoman atas "in uridu ilal islah" dan "watawa shaoubil haq watawa shaubil shabr".

\section{DAFTAR PUSTAKA}

A.F. Jaelani. (1997). Penyucian Jiwa dan Kesehatan Mental. Jakarta: Penerbit Amzah.

Achmad, M. (2008). Teknik Simulasi dan Permodelan. Yogjakarta: Universitas Gajah Mada.

Ahmad Tafsir. (1994). Ilmu Pendidikan dalam Perspektif Islam (R. Karya, ed.). Bandung.

Akhmad Alim. (2018). Pendidikan Jiwa: Terapi Spritual Manusia Modern,. Jakarta: Al Mawardi Prima.

Ali Abdul Halim Mahmud. (2000). Pendidikan Ruhani. Jakarta: Gema Insani.

Alle, J. G. (1969). Webster's New Satnar Dictionary. New York: Mc. Laughlin Brothers, Inc.

Anas Ahmad Karzon. (2016). Tazkiyatun Nafs. Jakarta: Akbarmedia.

Arifin, M. (2014). Filsafat Pendidikan Islam. Jakarta: Bumi Perkasa.

Baharuddin. (2007). Paradigma Psikologi Islam. Yogjakarta: Pustaka Pelajar.

Basrowi, S. (2009). Memahami Penelitian Kualitatif. Jakarta: Rineka Cipta.

Beekun, R. I., \& Badawi, J. A. (1999). Leadership: an Islamic perspective. Amana Beltsville, MD.

Burhanuddin, Y. (2005). Analisis Administrasi Manajemen dan Kepemimpinan Pendidikan. Jakarta: PT. Bumi Aksara.

Dardaa Mohamad, A., Hanin Hamjah, S., \& Irdha Mokhtar, A. (2017). Konsep Tazkiyah al-Nafs Menurut al-Harith bin Asad al-Muhasibi The Concept Of Tazkiyah al-Nafs According To alHarith Bin Asad al-Muhasibi. Jurnal Sultan Alauddin Sulaiman Shah, 4(1), 115-125.

Dhia’uddin, M. (2002). Islam \& Khilafah,. Jakarta: Lentera Basritama.

Drajat, Z. (2009). Ilmu Pendidikan Islam. Jakarta: Bumi Aksara.

Fadhlali, A. (2004). Sejarah Peradaban Islam. Jakarta: Pustaka Arruss.

Falah, S. (2012). Rindu Pendidikan dan Kepemimpinan M. Nastir. Jakarta: Republika.

Ghofar M. Abdul et.al. (2010). Tafsir Ibnu Katsir (Terj.), jilid 1. Jakarta: Pustaka Imam As-Syafi'i. Hamat, A. Al. (2015). Tarbiyah Jihadiyah Imam Bukhari. Jakarta: Ummul Quro.

Hamid Permadi. (2011). Metode Penelitian Pendidikan. Bandung: Alfabeta.

Hasan Langgulung. (1992). Asas-Asas Pendidikan Islam,. Jakarta: Pustaka Al-Husna.

Hasan Langgulung. (2002). Peralihan Paradigma dalam Pendidikan Islam dan Sains Sosial. Jakarta: Gaya Media Pratama.

Hawa, S. (1998). Intisari Ihya Ullumuddin Tazkiyatun Nafs, . Jakarta: Robbani Pres.

Ibn Taimiyah. (1994). Tazkiyah An Nafs. Riyadh: Daar Al Muslim Maktabah Al Malik Fahd. 
Imam Imamudiin Ibnu Katsir. (1420). Tafsir Al-Qur'an Al Adzim (Daar Thoyy).

Irham, F. (2013). Manajemen Kepemimpinan Teori dan Aplikasi. Alfabeta, Bandung.

Jean McNiff and Jack Whitehed. (2006). Action Research. California Sage Publication, 3.

Kahyo, K. P. (2005). Dasar-Dasar kepemimpinan. Jakarta: Sinar Grafika.

Kartono, K. (2010). Pemimpin Dan kepemimpinan, Jakarta: Raja Grafindo.

Lajnah Pentashihan Mushaf Al-Qur'an Kemenag RI. (2010). Spritual dan Akhlak: Tafsir Al-Qur'an Tematik. Jakarta: Penerbit Aku Bisa.

Langgululung, H. (1995). Beberapa Pemikiran Tentang Pendidikan Islam. Bandung: Al Ma'arif.

Langgulung, H. (2002). Peralihan paradigma dalam pendidikan Islam dan sains sosial. Gaya Media Pratama.

Lexy J. Moleong. (2011). Lexy J. Moleong,. Bandung: Rosda Karya.

Margono. (2013). Metodologi Penelitian Pendidikan,. Bogor: Widya Sakti.

Mubarakfuri, S. S. Al. (2001). Ar Rohiiq Al Makhtum. Jakarta: Mulia Sarana Press.

Muhaimin. (2012). Manajemen Pendidikan Aplikasi dalam Penyusunan Rencana Pengembangan Sekolah/Madrasah. Jakarta: Kencana Prenada.

Muhammad, N. A. B. (2007). Ringkasan Shahih Bukhori Jilid ke 2. Jakarta: Pustaka Azzam.

Muhyani., Herawati. S., dan H. H. (2019). Hubungan Pola Asuh Orang Tua Dengan Kepribadian Siswa Dan Penyalahgunaan Media Sosial Di Sman 2 Kota Bogor. Jurnal Pendidikan Islam, 08(1), 253-256.

Muslih Muhammad. (2002). Membangun Kesehatan Jiwa. Bandung: Pustaka Hidayah.

Pratt, H. (1960). Dictionary Of Sosiologi And Related Sciences. New Jersey: Littleifeld Adam \& Co. Paterson.

Putra, N. P. (2013). PENGARUH KEPEMIMPINAN, MOTIVASI, LINGKUNGAN KERJA, DAN DISIPLIN KERJA TERHADAP KINERJA KARYAWAN PADA PT. INDONESIA POWER SEMARANG. 0-1.

Rivai, V. (2009). Kepemimpinan dan Prilaku Organisasi. Jakarta: Raja Press.

Robbins, S. P. (2002). Prinsip-prinsip Perilaku Organisasi. Jakarta: Erlangga.

Selcta, R. (2008). 5 Pilar kepemimpinan. Jakarta: Nafiri Gabriel.

Shadily, J. M. E. dan H. (1989). Kamus Inggris Indonesia, An english - Indonesian Dictionary,. Jakarta: Gramedia Pustaka Utama.

Shoni R. A. (2012). The Power of Rasululloh Leadership, Menelusuri Prilaku Uswah Sifat Fundamental Kepemimpinan Rasululloh SAW, (Sabil). Yogjakarta.

Sugiyono. (2017). Metode Penelitian Kuantitatif, Kualitatif, Dan R\&D. Jakarta: Alfabeta.

Sutrisno, E. (2011). Manajemen Sumber Daya Manusia, Cetakan Kelima. Jakarta: Kencana Prenada Media Group.

Taimiyyah, I. (1969). Al-Siyasah Al-Syar'iyyah fi Ishlah al-Ra'i wa al-Ra'iyyah. Mesir: Daar al Kitab al-'Arabi.

Thabari, I. I. J. A. (1420). Jami Al Bayan An Ta'wil Ayat Al-Qur'an. Muasassah Ar Risalah.

W.I., M. (2015). Manajemen Dakwah. Jakarta: Prenada Media Group.

Yunan M. Yusuf. (2010). Tafsir Juz Amma. Jakarta: Pustaka Prima.

Zarkasyi, S. A. (2011). Bekal Untuk Pemimpin. Ponorogo: Trimurti Press. 
Islamic Management: Jurnal Manajemen Pendidikan Islam Doi: 10.30868/im.v4i01.899
P-ISSN: 2614-4018

E-ISSN: 2614-8846

Zuhairi. (2009). Filsafat Pendidikan Islam. Jakarta: Bumi Aksara. 